\title{
Perbandingan Strategi dan Pola Pengembangan Pesantren dan Diniyyah Berwawasan Multikultural
}

\author{
Miftahul Huda', Rhoni Rodin ${ }^{2}$ \\ ${ }^{1}$ Universitas Islam Negeri Syarif Hidayatullah Jakarta \\ 2 Institut Agama Islam Negeri Curup
}

Keywords: strategy, development pattern, pesantren, diniyyah, multicultural

\footnotetext{
*Correspondence Address: rhoni.rodin@iaincurup. ac.id
}

Abstract: The purpose of this study are: (1) to determine the educational system, strategies, and various patterns of pesantren development with a multicultural perspective; (2) to determine the education system, strategies, and various patterns of diniyyah development with a multicultural perspective; (3) to compare systems, strategies and patterns of education in pesantren and diniyyah with multicultural insight. In this study using a qualitative approach. The method used is a research library. The data analysis technique used is content analysis. The result of this research is that multicultural education at the pesantren is reflected in the content of the curriculum that teaches students insights on the diversity of beliefs such as teaching special material muqāranat aladyān. Secondary formal diniyyah education consists of formal ulya diniyyah education and ma'had Aly. Strategies and development patterns in Diniyyah that have a multicultural perspective through a curriculum, namely extracurricular and intracurricular subjects and activities.

Abstrak: Tujuan dari penelitian ini adalah: (1) untuk mengetahui sistem pendidikan, strategi, dan macammacam pola pengembangan pesantren berwawasan multikultural; (2) untuk mengetahui sistem pendidikan, strategi, dan macam-macam pola pengembangan diniyyah berwawasan multikultural; (3) untuk mengetahui perbandingan sistem, strategi dan pola pendidikan di pesantren dan diniyyah yang berwawasan multikultural. Dalam penelitian ini menggunakan pendekatan kualitatif. Metode yang dipergunakan adalah library research. Teknik analisis data yang digunakan adalah analisis isi (Content analysis). Adapun hasil dari penelitian ini adalah pendidikan multikultural di pesantren tercermin dari muatan isi kurikulum yang mengajarkan wawasan santri akan keragaman keyakinan seperti, diajarkan materi khusus muqāranat al-adyān. Pendidikan diniyyah formal menengah terdiri atas pendidikan diniyyah formal ulya, dan ma'had Aly. Strategi dan pola pengembangan di diniyyah yang berwawasan multikultural ini melalui kurikulum yaitu mata pelajaran dan kegiatan ekstrakurikuler serta intrakurikuler. 


\section{PENDAHULUAN}

Indonesia merupakan salah satu negara yang terbesar populasi penduduknya di dunia. Indonesia juga merupakan negara yang majemuk. Kemajemukannya ditandai dengan beragam etnis, suku, budaya, agama, bahasa, dan adat istiadat di dalamnya. Ada hampir 1500 suku bangsa yang tersebar di 17.000 pulau dan berbagai bahasa . ${ }^{1} \mathrm{Hal}$ ini adalah kekayaan yang harus di jaga bersama, tetapi di sisi lain kemajemukam tersebut dapat mengancam disintegrasi bangsa apabila tidak dikelola dengan baik. Sebagaimana beberapa tahun lalu kita telah menyaksikan beberapa tragedi kekerasan yang bernuansa etnik/agama yang melanda Ambon, Sambas/Sampit, Poso, yang tidak mustahil bisa kembali berulang di masa depan. Oleh karena itu, berbagai upaya dilakukan untuk meminimalisir dan mengelola berbagai perbedaan yang ada di masyarakat.

Perbedaan kebudayaan yang disebutkan dikenal dengan istilah multikultural. Dalam situasi multikultural ini, dunia pendidikan mampu menyandarkan dan membawa pesan-pesan yang universal agar mengurangi konflik-konflik antar kultur. Guna menghindari munculnya aksi intoleransi, kekerasan, konflikkonflik bernuansa SARA ${ }^{2}$, baik itu di dunia pendidikan ataupun di dunia politik masyarakat. Jadi pendidikan multikultural adalah suatu keniscayaan. Ia merupakan paradigma

\section{Sosial",}

${ }^{1}$ Pordam, "Jurus Kemensos Cegah Konflik https://www.antaranews.com/berita/187070 4/pordam-jurus-kemensos-cegah-konflik-

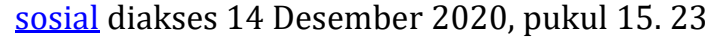
WIB.

2 SARA singkatan dari Suku, Agama, Ras, Antar golongan. dan metode untuk menggali potensi keragaman etnik dan kultural nusantara, dan mewadahinya dalam suatu manajemen konflik. ${ }^{3}$

Pendidikan multikultural walaupun wacana baru dalam konteks pendidikan Indonesia, tetapi dalam praktiknya telah lama ada dalam sejarah kehidupan bangsa Indonesia, seperti semangat persatuan untuk meraih kemerdekaan, gotong royong, toleransi antar umat beragama, dan sebagainya. Oleh karena itu pendidikan multikultural menjadi alternatif paradigma pendidikan nasional termasuk dalam pendidikan keagamaan Islam, karena salah satu tujuan pendidikan keagamaan Islam ialah mengembangkan pribadi akhlakul karimah bagi peserta didik yang memiliki kesalehan individual dan sosial dengan menjunjung tinggi jiwa keikhlasan, kesederhanaan, kemandirian, persaudaran sesama umat Islam (ukhuwah Islamiyah), rendah hati (tawadhu), toleran (tasamuh), keseimbangan (tawazun), moderat (tawasuth), keteladanan (uswah), pola hidup sehat, dan cinta tanah air. ${ }^{4}$ Hal ini sejalan dengan paradigma pendidikan multikultural yang menjunjung tinggi kesetaraan dan kesamaan dalam kehidupan merupakan salah satu upaya untuk meminimalisir berbagai konflik sosial yang ada di tengah masyrakat yang berbeda.

Pendidikan keagamaan Islam ini menurut Peraturan Menteri Agama Republilk Indonesia No 13 Tahun

3 Zakiyuddin Baidhawy, Pendidikan Agama Berwawasan Multikultural, (Jakarta: Erlangga, 2005), 17.

4 Peraturan Menteri Agama Republilk Indonesia No 13 Tahun 2014 Tentang Pendidikan keagamaan Islam pasal 2C. 
2014, terdiri dari pesantren dan pendidikan diniyyah. ${ }^{5}$ Eksistensi pesantren dan diniyyah turut memberikan kontribusi yang signifikan dalam mencerdaskan bangsa Indonesia. Pesantren memiliki tanggung jawab besar dan peran strategis dalam mengembangkan pendidikan Islam berwawasan multikultural. Hal ini disebabkan pesantren merupakan lembaga pendidikan awal yang banyak mencetak agamawan dan intelektual muslim. Lembaga ini secara emosional dan kultural sangat erat kaitannya dengan masyarakat akar rumput. Untuk itu, lulusan pesantren menjadi sangat strategis dalam perannya mengembangkan pendidikan Islam yang berwawasan multikultural. ${ }^{6}$

Sedangkan pendidikan diniyyah merupakan pendidikan keagamaan Islam yang diselenggarakan pada semua jalur dan jenjang pendidikan. ${ }^{7}$ Jauh sebelum Indonesia merdeka, perguruan-perguruan keagamaan sudah lebih dulu berkembang. Selain menjadi akar budaya bangsa, agama secara sadar merupakan bagian tak terpisahkan dalam dinamika pendidikan. Pendidikan keagamaan pun berkembang sebagai bagian dari mata pelajaran pendidikan agama yang di nilai menghadapi berbagai keterbatasan. Sebagian masyarakat mengatasinya dengan tambahan

5 Peraturan Menteri Agama Republilk Indonesia No 13 Tahun 2014 Tentang Pendidikan keagamaan Islam pasal 3.

6 Ali Muchasan, "Pendidikan Islam Multikultural di Pesantren (studi kasus di pondok pesantren Sirrojul Ulum Semanding Pare Kediri)", Jurnal Inovatif, Vol 4 No 1 Februari 2018, 79.

7 Peraturan Pemerintah Republik Indonesia No 55 Tahun 2007 Tentang Pendidikan Agama dan Keagamaan, pasal 1 ayat 3 . pendidikan agama di rumah-rumah ibadah atau di perkumpulanperkumpulan yang kemudian berkembang menjadi satuan pendidikan keagamaan formal dan nonformal. ${ }^{8}$

Dengan demikian tulisan ini akan membahas strategi dan pola pengembangan pesantren dan diniyyah yang berwawasan multikultural dilihat dalam kacamata perbandingannya mulai dari persamaan, perbedaan, antara kedua pendidikan keagamaan Islam tersebut. Oleh karena itu, penulis tertarik untuk mengangkat tema dalam penelitian ini yang berjudul "Perbandingan Strategi dan Pola Pengembangan Pesantren dan Diniyyah Berwawasan Multikultural". Diharapkan tulisan ini mampu memberikan kontribusi positif khususnya dalam bidang perbandingan pendidikan multikultural dan umumnya untuk seluruh akademisi di Indonesia.

\section{METODE PENELITIAN}

Penelitian ini merupakan penelitian kualitatif dengan analisis deskriptif yang bersifat kepustakaan (library research). Data-data penelitian ini diperoleh dari berbagai literatur, baik yang berkaitan dengan aspek konsep-konsep maupun teori yang berhubungan dengan konsep keilmuan pesantren dan diniyyah maupun sumber lainnya yang berkaitan pengembangan dan strategi pendidikan multikultural. Sumber data tersebut bisa berbentuk buku atau tulisan-tulisan lainnya yang berhubungan dengan topik penelitian yang dibahas.

8 Anis Fauzi, "Pelaksanaan Pendidikan Madrasah Diniyah di Kota Serang”, Jurnal Pendidikan dan Kebudayaan, Vol 1, Nomor 2 , 2016, 159. 
Adapun teknik pengumpulan data dilakukan dengan teknik dokumentasi yaitu memanfaatkan informasi yang terdapat di perpustakaan dan jasa informasi lain yang tersedia. Penelitian ini sematamata dilakukan dengan membaca dan menelaah sumber-sumber data primer maupun sekunder.

Guna menjawab rumusan masalah yang diajukan dalam penelitian ini, maka metode analisis data yang penulis gunakan adalah metode deskriptif analitik, yaitu data yang diperoleh berupa kata-kata, gambar dan prilaku yang tidak dituangkan dalam bentuk bilangan atau statistik, melainkan tetap dalam bentuk kualitatif dengan memberi pemaparan gambaran mengenai situasi yang diteliti dalam bentuk uraian naratif. ${ }^{9}$ Jadi secara terperinci dengan menggunakan metode deskriptif kualitatif lebih menggambarkan apa adanya tentang suatu variabel, gejala atau keadaan. ${ }^{10}$

Selanjutnya tehnik analisis data menggunakan metode analisis isi (content analysis). Analisis ini memanfaatkan prosedur yang dapat menarik kesimpulan shahih dari sebuah buku atau dokumen yang digunakan untuk mendeskripsikan subyek penelitian. Proses content analysis dimulai dengan penyortiran pesan komunikasi tersebut, dipilahpilah kemudian dilakukan kategorisasi (pengelompokan) antara data yang sejenis, dan selanjutnya dianalisis secara kritis dan obyektif. Berdasarkan penjelasan tentang content analysis di atas, maka secara umum langkahlangkah analisis yang ditempuh dalam penelitian ini sebagai berikut: pertama,

\footnotetext{
9 Margono, Metode penelitian pendidikan, (Jakarta: Rineka Cipta, 2000), 39

10 Suharsimi Ari Kunto. Management Penelitian, (Jakarta: Rineka Cipta, 2000), 310.
}

pengadaan data, yang terdiri dari penentuan satuan, perekaman atau pencatatan data yang diperlukan, baik dari sumber primer atau sumber skunder, kedua, pengurangan data, ketiga inferensi, dan keempat adalah analisis. Menganalisis data yang telah terhimpun kemudian dituangkan atau disajikan dalam bentuk tulisan.

\section{HASIL DAN DISKUSI \\ Sistem Pendidikan di Pondok Pesantren Multikultural \\ Berwawasan}

Pesantren adalah lembaga pendidikan keagamaan Islam yang diselenggarakan oleh masyarakat yang menyelenggarakan satuan pendidikan pesantren dan atau secara terpadu menyelenggarakan jenis pendidikan lainnya. ${ }^{11}$ Pesantren sebenarnya tidak hanya identik dengan makna ke-Islaman, tetapi juga mengandung makna keaslian Indonesia. Sebab keberadaannya sudah mulai dikenal di Indonesia pada awal abad ke 13-17 M, dan dikenal di pulau jawa pada abad ke 15-16 M. ${ }^{12}$ pada dasarnya pesantren merupakan tempat pendidikan dan pengajaran yang menekankan pelajaran agama dan didukung dengan asrama sebagai tempat tinggal santri yang bersifat permanen selama santri tersebut masih belajar di pesantren. ${ }^{13}$ Kemudian seiring perkembangan zaman, pesantren juga melakukan beberapa perubahan dan perkembangan dalam sistem pendidikannya, di samping tetap

11 Permenang No 13 Tahun 2014 Tentang Pendidikan keagamaan Islam pasal 1

12 Muhtarom, Reproduksi Ulama di era global: Resistensi Tradisional Islam, (Yogyakarta: Pustaka Pelajar, 2005), 5.

13 Mujamil Qomar, Pesantren: Dari Transformasi Metodologi Menuju Demokratisasi Institusi. (Jakarta: Erlangga, 2004), 2. 
mempertahankan ciri khas kepesantrenannya.

Pesantren sebagai manifestasi pendidikan Islam tradisional dan subkultur pendidikan di Indonesia, ${ }^{14}$ mulai mengakomodir tuntutan perubahan sosial, tidak sedikit konstruksi pesantren melakukan transformasi menjadi lembaga pendidikan modern dengan mengadopsi kurikulum pemerintah dan kurikulum yang dikembangkan lembaga pendidikan umum. ${ }^{15}$ Oleh karena itu, beberapa pesantren mengintegrasikan kurikulum yang berasal dari pemerintah dan kurikulum yang murni dari pesantren dengan tujuan untuk membekali santrinya tidak hanya tafaqquh fi al-din tetapi juga memiliki kemampuan atas ilmu umum. ${ }^{16}$ Demikian pula, perjalanan dalam mengimplementasikan nilai-nilai Islam tidak hanya berdiri dibangun di atas teks suci Al Quran dan Hadits. Namun, metode mengaktualisasikannya memerlukan dialektika panjang antara teks suci yang bersumber dari wahyu dan cenderung otoritatif dengan kultur tradisi masyarakat Indonesia yang lebih bersifat lokalistik bahkan mengadopsi budaya leluhur. Di sinilah pentingnya, mempelajari dan mendalami hasil "kompromi" antara teks dan konteks dalam Islam ala

14 Baharun \& Awwaliyah, "Pendidikan Multikultural dalam Menanggulangi Narasi Islamisme di Indonesia". Jurnal Pendidikan Agama Islam (Journal of Islamic Education Studies), 2017, 5 (2), 224-243.

15 Mastuhu. Dinamika Sistem Pendidikan Pesantren: Suatu Kajian Tentang Unsur dan Nilai Sistem Pendidikan Pesantren. (Jakarta: INIS, 1994), 24.

16 Fauzi, A. "Pengembangan Human Relation Perspektif Nilai-nilai alQuran". Mutawatir UIN Sunan Ampel Surabaya, 2015, 1 (2), 168-179.
Indonesia. Sebab, perkembangan Islam di bumi nusantara ini sangat dinamis dan progresif. Meskipun sekilas tampak tidak ada perubahan, namun bila diamati secara detail interpretasi terhadap nilai-nilai Islam cenderung dinamis.

Lebih-lebih diperkuat dan dijelaskan dalam Permenag no 13 tahun 2014 tentang pendidikan keagamaan Islam, sistem pendidikan di pesantren wajib menjunjung tinggi dan mengembangkan nilai-nilai Islam rahmatan lil'alamin dengan menjunjung tinggi nilai-nilai Pancasila,Undang-Undang Dasar 1945, Negara Kesatuan Republik Indonesia, Bhineka Tunggal Ika, keadilan, toleransi, kemanusiaan, keikhlasan, kebersamaan, dan nilai-nilai luhur lainnya. ${ }^{17}$ Hal ini sejalan dengan nilainilai pendidikan multikultural dalam pendidikan agama Islam yang sangat menjunjung tinggi toleransi, pancasila, bhineka tunggal ika untuk mewujudkan Islam rahmatan lil'alamin. Secara implisit, paradigma pendidikan multikultural menjadi perhatian dalam pasal 4 undangundang nomor 20 tahun 2003 tentang sistem pendidikan nasional. Yang mana dalam pasal itu disebutkan bahwa: Pendidikan diselenggarakan secara demokratis dan berkeadilan serta tidak diskriminatif dengan menjunjung tinggi hak asasi manusia, nilai keagamaan, nilai kultural, dan kemajemukan bangsa. ${ }^{18}$

Pesantren wajib memiliki unsur-unsur pesantren yang terdiri atas: kyai atau sebutan lain yang sejenis; santri; pondok atau asrama

17 Permenang No 13 Tahun 2014 Tentang Pendidikan keagamaan Islam pasal 4

18 Undang-Undang Republik Indonesia Nomor 20 tahun 2003 tentang Sistem pendidikan nasional pasal 4 . 
pesantren; masjid atau musholla, dan pengajian dan kajian kitab kuning atau dirasah islamiyah dengan pola pendidikan mu 'allimin. ${ }^{19}$

Kyai adalah orang yang berpendidikan pesantren dan memiliki kompetensi ilmu agama Islam yang bertugas membimbing, mengasuh, dan mengajarkan santri. Santri ialah peserta didik dan wajib bermukin di pondok atau asrama pesantren.

Pesantren sebagai satuan pendidikan merupakan pesantren yang menyelenggarakan pengajian kitab kuning atau dirasah islamiyah dengan pola pendidikan mu'allimin. Penyelenggaraan kitab kuning dapat dilakukan dalam bentuk pengajian kitab kuning pada umumnya dan/atau program takhassus pada bidang ilmu keislaman tertentu sesuai dengan ciri khas dan keunggulan masing-masing pesantren. Penyelenggaraan dirasah islamiyah dengan pola pendidikan $m u$ 'allimin dilakukan secara integratif dengan memadukan ilmu agama Islam dan ilmu umum dan bersifat komprehensif dengan memadukan intra, ekstra, dan kukurikuler. ${ }^{20}$

Muatan kurikulum pesantren sebagai satuan pendidikan meliputi AlQuran, Tafsir, Ilmu Tafsir, Hadits, Ulum Al-Hadits, Tauhid, Fiqh, Ushul Fiqh, Akhlak, Tasawuf, Tarikh, Bahasa Arab, Nahwu-Sharf, Balaghah, Ilmu Kalam, Ilmu 'Arudl, Ilmu Manthiq, Ilmu Falaq, dan disiplin ilmu lainnya. Selain muatan kurikulum tersebut pesantren dapat menyelenggarakan program takhasus yang meliputi tahfizh alQur'an, ilmu falaq, faraid, dan cabang dari ilmu keislaman lainnya. ${ }^{21}$

19 Permenang No 13 Tahun 2014 Tentang

Pendidikan keagamaan Islam pasal 5

20 Permenang No 13 Tahun 2014 Tentang

Pendidikan keagamaan Islam pasal 13

21 Permenang No 13 Tahun 2014 Tentang

Pendidikan keagamaan Islam pasal 14
Penjenjangan santri didasarkan atas penguasaan yang bersangkutan terhadap tingkatan kitab kuning atau dirasah islamiyah dengan pola pendidikan mu 'allimin yang diajarkan. ${ }^{22}$ Kyai atau pendidik pada pesantren melakukan penilaian atas perkembangan, kemajuan dan hasil belajar santri. ${ }^{23}$ Dengan demikian santri dapat diklasifikasikan tingkat belajarnya sesuai tingkat kemampuannya.

Salah satu pesantren yang mengimplementasikan pendidikan multikultural adalah Pondok Pesantren Sirojul Ulum Semanding, Tertek, Pare, Kediri, Jawa Timur. Keutamaan pendidikan multikulturalisme di pondok modern juga tercermin dari muatan/isi kurikulum yang mengajarkan wawasan santri akan keragaman keyakinan. Dalam kelompok bidang studi Dirasah Islamiyah, sebagai contoh, diajarkan materi khusus muqāranat al-adyān (Perbandingan Agama) yang konten luasnya memaparkan sejarah, doktrinisme, fenomena dan dinamika keagamaan di dunia. Materi ini sangat substansial dalam pendidikan multikulturalisme, karena santri diwawaskan berbagai perbedaan mendasar keyakinan agama mereka (Islam) dengan agama-agama lain di dunia. 24 Materi ini sangat potensial membangun kesadaran toleransi keragaman keyakinan yang akan para santri temui saat hidup bermasyarakat kelak.

22 Permenang No 13 Tahun 2014 Tentang Pendidikan keagamaan Islam pasal 16

23 Permenang No 13 Tahun 2014 Tentang Pendidikan keagamaan Islam pasal 17.

${ }^{24}$ Ali Muchasan, "Pendidikan Multikultural di Pesantren (Studi Kasus Pada Pondok Pesantren Sirojul Ulum Semanding Pare Kediri)", Jurnal Inovatif, vol 4 no 1, Februari 2018, 85-88. 
Dengan demikian peserta didik akan menghindari sikap dan perilaku diskriminatif, hegemonik, dan dominatif. Dan dapat menekan sikap permusuhan, konflik, kekerasan dan mau menang sendiri .

\section{Strategi Pembelajaran Di Pondok Pesantren Multikultural Berwawasan}

Strategi pembelajaran di pondok pesantren, dalam PMA No. 13 tahun 2014 yaitu santri wajib bermukim di pondok atau asrama. Hal ini dimaksudkan agar proses pendidikan lebih intensif, baik yang menyangkut pengamalan ibadah, pemahaman keagamaan, penguasaan bahasa asing, internalisasi nilai-nilai keagamaan dan akhlak karimah, serta peningkatan keterampilan. ${ }^{25}$

Di pesantren diterapkan tradisi atau wajib tinggal di asrama dimana setiap santri terlatih untuk menolong yang lain, disiplin untuk meneguhkan kepribadian serta saling menghormati. Pesantren dengan kelebihan pendidikan intens 24 jamnya, memiliki banyak waktu untuk menyisipkan aneka pendidikan. Salah satunya multikulturalisme. Pola umum yang nyaris diberlakukan di berbagai pesantren adalah sistem pendidikan multikultur yang menyatu dalam aturan dan disiplin pondok. Salah satunya dalam urusan penempatan pemondokan (asrama) santri.

Pengajian dan kajian kitab kuning dilakukan dengan menggunakan kitab kuning sebagai sumber belajar sesuai dengan tingkatan peserta didik. Dirasah islamiyah dengan pola pendidikan mu'allimin dilakukan dengan

25 Permenang No 13 Tahun 2014 Tentang Pendidikan keagamaan Islam pasal 7. pendekatan tematik sesuai dengan kekhasan masing-masing pesantren.

Pembelajaran kitab kuning dilakukan dengan menggunakan metode sorogan (individual), metode bandongan (massal), metode bahtsul masail, dan metode lainnya. Pembelajaran dirasah islamiyah dengan pola pendidikan mu 'allimin dilakukan dengan metode klasikal, terstruktur, dan berjenjang sesuai dengan struktur kurikulum yang ditetapkan oleh pesantren. ${ }^{26}$

Metode sorogan yang dalam praktiknya dilaksanakan dalam suatu ruangan dengan adanya Kyai dan seorang santri yang saling berhadapan dan santri yang lain menyimak di belakang sambil menunggu giliran. ${ }^{27}$ Santri yang sedang sorogan dengan Kyai membawa sebuah kitab dengan materi yang sudah ditentukan sebelumnya untuk dilihat kemampuannya dalam membaca dan menguasai materi yang ada di kitab. ${ }^{28}$ Metode sorogan memiliki beberapa nilai keunggulan, diantaranya: terjalin hubungan yang harmonis antara pendidik dan peserta didik, memungkinkan bagi pendidik untuk membimbing secara maksimal peserta didiknya, pendidik mengetahui secara pasti kualitas peserta didiknya. Kelemahan metode ini adalah banyak memakan waktu dan memerlukan pendidik yang lebih banyak.

Sedangkan Metode bandongan atau juga disebut dengan wetonan. Pengertian bandongan secara bahasa berasal dari ngabandungan yang

26 Peraturan Menteri Agama Republilk Indonesia No 13 Tahun 2014 Tentang Pendidikan keagamaan Islam pasal 15.

27 Manfred Ziemek, Pesantren dan Perubahan Sosial, (Jakarta: P3M, 1986), h. 68.

28 Hasbullah, Sejarah Pendidikan Islam di Indonesia, (Raja Grafindo Persada: Jakarta, 1995), 26. 
artinya menyimak atau memperhatikan secara seksama. Sedangkan secara istilah adalah transfer keilmuan di pondok pesantren (klasik) dengan cara pengajar membacakan kitab, menerjemahkan dan menerangkan sedangkan para santri menyimak, memahami, dan mencatat apa yang diajarkan. ${ }^{29}$ Metode bandongan memiliki beberapa nilai keunggulan, diantaranya: pemahaman yang baik karena pengajarannya sering diulang-ulang, sangat efisien dalam mengajarkan ketelitian suatu materi yang sulit, meminimalisir pemahaman yang melenceng dari materi yang telah ada. Kekurangannya adalah Kreativitas santri sulit muncul karena pengajaran bersifat monolog murid cenderung cepat bosan karena metodenya kurang interaktif. 30

Di samping metode sorogan dan bandongan, dalam dunia pesantren (klasik) juga dikenal metode Bathsul Masail. Metode ini dilaksanakan setiap seminggu sekali ataupun sebulan sekali. Dalam praktiknya, metode Bathsul Masail digunakan oleh para santri untuk mengasah dalam hal menyelesaikan masalah dengan kajiankajian yang sebelumnya telah diperoleh.

Salah satu contoh pesantren yang berwawasan multikultral yang menerapkan strategi atau metode pembelajaran ini adalah pesantren Nurul Ummah Yogyakarta. Pondok pesantren ini menerapkan pendidikan multikulturalnya melalui budaya. ${ }^{31}$

29

https://pontren.com/2016/01/13/metodebandongan-pada-pondok-pesantren/ diakses pada tanggal 18 Desember 2020, pukul 15. 41 WIb.

30 Ditpekapontren Kemenag Republik Indonesia (2003: 78)

31 Khumaidah dan Ridwan Alawi Sadad, "Analisis Pendidikan Multikultural di Madrasah dan Pesantren: Studi Komparasi di
Budaya yang tedapat pada Pondok Pesantren Nurul Ummah yaitu terkait dengan kegiatan rutin yang dilaksanakan. Misalnya setiap hari Kamis malam Jum'at merupakan kegiatan aktivitas santri. Setiap malam Jum'at itu ada malam Jum'at kliwon khusus mujadah, malam Jum'at pahing untuk kegiatan perkenalan, malam Jum'at wage untuk sholat tasbih dan setelah sholat ada sima'an. Kegiatan rutinan yang lain juga ada tradisi masa'id yang diibaratkan misalnya kalau di akademik yaitu ILC. Para santri tersebut membahas isu-isu yang bisa dibahas dan mereka juga mempunyai dasar masing-masing. Selain itu, terkadang juga ada kegiatan musyawarah (metode Bathsul Masail) yang misalnya membahas masalah hukum, seperti hukum fiqih. Metode pembelajaran dalam pesantren ini juga menggunakan metode sorogan untuk kelas 1 awaliyah hingga kelas 3, sedangkan untuk kelas 4 awaliyah sudah menggunakan metode diskusi.

Hal ini sudah sesuai dengan nilai-nilai pendidikan multikultural yang salah satunya adalah musyawarah.

\section{Pola Pengembangan Di Pondok Pesantren Multikultural Berwawasan} Untuk mengembangkan pendidikan agama Islam yang rahmatan lil alamin ada dua pendekatan: pertama, dengan pendekatan penguatan budaya yang bersifat transformatif dengan

MAN 3 Sleman dan Pondok Pesantren Nurul Ummah Kotagede Yogyakarta", Penangkaran: Jurnal Penelitian Agama dan Masyarakat, Vol 2 No. 1, tahun 2018. H. 109-110. http://ejournal.uin-

suka.ac.id/pusat/panangkaran/article/view/1 $\underline{872}$ diakses tanggal 18 Desember 2020 , pukul 16. 22 WIB. 
mengakomodir kearifan-kearifan lokal yang diakui di masyarakat, dan yang kedua, dengan pendekatan sufistik atau tasawuf yang bersifat batiniyah sehingga ajaran-ajaran agama yang kita pahami bersifat humanis dan toleran.

Dengan demikian, pola pengembangan pondok pesantren yang berwawasan multikultural melalui literatur-literatur yang menjadi rujukan kitab kuning para santri. Seperti contohnya pondok pesantren Darul Ihya 'Ulumuddin dan Darul Lughah Wadda'wah Bangil yang sangat kental dengan pendidikan tasawuf. Karena proses implementasi pendidikan tawasuf dapat mencegah radikalisme agama. Pondok pesantren ini mengakaji kitab Ihya 'Ulumuddin karya imam al-Ghazali yang merupakan kitab yang membahas tent ang kaidah dan prinsip dalam menyucikan jiwa (Tazkiyatun Nafs) yang membahas perihal penyakit hati, pengobatannya, dan mendidik hati. Dengan mempelajari kitab tersebut diharapkan santri dapat lebih toleransi dalam menghadapi berbagai aspek kehidupan. Dan di pondok pesantren tersebut mengkaji kitab Tanbihul Mughtarin, dengan tema yang diajarkan dengan cinta dan persaudaraan. ${ }^{32}$

Hal ini sejalan dengan prinsipprinsip multikulturalisme yang ditawarkan dalam alQuran,33 antara lain: prinsip persamaan, kebebasan,

32 Muhammad Idrus, Implementasi Pendidikan Tasawuf di Pondok Pesantren dalam Upaya Mencegah Praktek Radikalisme Agama. (UIN Maulana Malik Ibrahim Malang: Tesis, 2019), 163.

33 Rohimin, "Menggagas PAI Multikultural Berbasis alQuran, Jejak dan Pengembangan Nilai-nilai Multikulturalisme dalam Pendidikan Agama Islam", NUANSA, Vol XI No. 2, Desember 2018, 76. persatuan dan persaudaraan, perdamaian, musyawarah, keadilan, kepemimpinan, tolong menolong dan membela, dan pertahanan.

\section{Sistem Pendidikan Diniyyah}

Pendidikan diniyyah merupakan pendidikan keagamaan Islam yang diselenggarakan pada semua jalur dan jenjang pendidikan. ${ }^{34}$ Menurut Peraturan Pemerintah Nomor 55 tahun 2007 tentang pendidikan agama dan pendidikan keagamaan, maka pendidikan diniyyah merupakan bagian dari pendidikan keagamaan Islam. Hal ini juga diperjelas dengan Peraturan Menteri Agama Nomor 13 Tahun 2014 tentang Pendidikan Keagamaan Islam, disebutkan dalam Permenag tersebut bahwa pendidikan keagamaan Islam terdiri dari (a) pesantren, dan (b) pendidikan diniyyah. ${ }^{35}$ Selanjutnya disebutkan bahwa pendidikan diniyyah terdiri atas (a) pendidikan diniyyah formal, (b) pendidikan diniyyah nonformal, dan (c) pendidikan diniyyah informal. ${ }^{36}$ Pendidikan diniyyah formal adalah lembaga pendidikan keagamaan Islam yang diselenggarakan oleh dan berada di dalam pesantren secara terstruktur dan berjenjang pada jalur pendidikan formal. ${ }^{37}$ Selanjutnya, Pendidikan diniyyah nonformal adalah pendidikan keagamaan Islam yang

34 Peraturan Pemerintah Republik Indonesia No 55 Tahun 2007 Tentang Pendidikan Agama dan Keagamaan, pasal 1 ayat 3 .

35 Peraturan Menteri Agama Republilk Indonesia No 13 Tahun 2014 Tentang Pendidikan keagamaan Islam pasal 3.

36 Peraturan Menteri Agama Republilk Indonesia No 13 Tahun 2014 Tentang Pendidikan keagamaan Islam pasal 20.

37 Peraturan Menteri Agama Republilk Indonesia No 13 Tahun 2014 Tentang Pendidikan keagamaan Islam pasal 1 ayat 7 . 
diselenggarakan dalam bentuk madrasah diniyyah takmiliyah, Pendidikan Al-Qur'an, Majelis Taklim, atau bentuk lain yang sejenis baik di dalam maupun di luar pesantren pada jalur pendidikan nonformal. ${ }^{38}$ Dan Pendidikan diniyyah informal adalah pendidikan keagamaan Islam dalam bentuk program yang diselenggarakan di lingkungan keluarga pada jalur pendidikan informal. ${ }^{39}$

Untuk lebih jelasnya mengenai pendidikan diniyyah ini merujuk pada Permenag Nomor 13 Tahun 2014 Tentang pendidikan Keagamaan Islam, lihat tabel di bawah ini sebagai berikut.

Tabel 1. Pendidikan Diniyyah

\begin{tabular}{|c|c|c|}
\hline \multicolumn{3}{|c|}{ Pendidikan Diniyyah } \\
\hline $\begin{array}{c}\text { Pendidika } \\
\text { n } \\
\text { Diniyyah } \\
\text { Formal }\end{array}$ & $\begin{array}{c}\text { Pendidi } \\
\text { kan } \\
\text { Diniyya } \\
\boldsymbol{h} \\
\text { Nonfor } \\
\text { mal }\end{array}$ & $\begin{array}{c}\text { Pendidika } \\
\text { n } \\
\text { Diniyyah } \\
\text { Informal }\end{array}$ \\
\hline $\begin{array}{l}\text { Jenjang } \\
\text { pendidika } \\
\text { n dasar: } \\
\text { ula } \\
\text { (MI/SD) } \\
\text { dan } \\
\text { wustha } \\
\text { (Mts/SMP) }\end{array}$ & $\begin{array}{l}\text { Madras } \\
\text { ah } \\
\text { diniyyah } \\
\text { takmiliy } \\
\text { ah (ula, } \\
\text { wustha, } \\
\text { ulya, } \\
\text { dan al- } \\
\text { jami'ah) }\end{array}$ & $\begin{array}{l}\text { Diselengga } \\
\text { rakan oleh } \\
\text { masyaraka } \\
\text { t dalam } \\
\text { bentuk } \\
\text { pendidika } \\
\text { n } \\
\text { Keagamaa } \\
\text { n Islam di }\end{array}$ \\
\hline $\begin{array}{l}\text { Jenjang } \\
\text { pendidika } \\
\text { n } \\
\text { menengah: } \\
\text { ulya }\end{array}$ & $\begin{array}{l}\text { Pendidi } \\
\text { kan } \\
\text { alQuran }\end{array}$ & $\begin{array}{l}\text { lingkungan } \\
\text { keluarga. }\end{array}$ \\
\hline
\end{tabular}

38 Peraturan Menteri Agama Republilk Indonesia No 13 Tahun 2014 Tentang Pendidikan keagamaan Islam pasal 1 ayat 8.

39 Peraturan Menteri Agama Republilk Indonesia No 13 Tahun 2014 Tentang Pendidikan keagamaan Islam pasal 1 ayat 9 .

\begin{tabular}{|c|c|}
\hline $\begin{array}{l}\text { (MA/SMA/ } \\
\text { SMK) }\end{array}$ & \\
\hline $\begin{array}{l}\text { Jenjang } \\
\text { pendidika } \\
\text { n tinggi: } \\
\text { Ma'had Aly }\end{array}$ & $\begin{array}{l}\text { Majelis } \\
\text { taklim } \\
\text { dan } \\
\text { pendidi } \\
\text { kan } \\
\text { keagam } \\
\text { aan } \\
\text { islam } \\
\text { lainnya }\end{array}$ \\
\hline
\end{tabular}

Dari tabel di atas pendidikan diniyyah formal terdiri atas pendidikan diniyyah formal jenjang pendidikan dasar, menengah, dan tinggi. pendidikan diniyyah dasar terdiri atas pendidikan pendidikan diniyyah formal ula dan wustha. Pendidikan diniyyah formal menengah terdiri atas pendidikan diniyyah formal ulya, dan pendidikan diniyyah formal jenjang pendidikan tinggi berbentuk ma'had Aly.

Pendidikan diniyyah formal ula merupakan pendidikan yang sederajat dengan madrasah ibtidaiyah/ sekolah dasar terdiri atas 6 tingkat. Pendidikan diniyyah formal wustha merupakan pendidikan yang sederajat dengan madrasah Tsanawiyah/ sekolah menengah pertama terdiri atas 3 tingkat. Pendidikan diniyyah formal ulya merupakan pendidikan yang sederajat dengan madrasah aliyah/ sekolah menengah atas/ sekolah menengah kejuruan terdiri atas 3 tingkat.

Kurikulum keagamaan Islam pada satuan pendidikan diniyyah formal ula paling sedikit harus memuat mata pelajaran: alQuran, hadist, tauhid, fiqih, akhklak, tarikh, dan bahasa arab. Kurikulum keagamaan Islam pada satuan pendidikan diniyyah formal wustha paling sedikit harus memuat mata pelajaran: alQuran, tafsir-ilmu tafsir, 
hadist-ilmu hadist, tauhid, fiqih-ushul fiqh, akhklak-tasawuf, tarikh, bahasa arab, nahwu-sharf, balaghah, dan ilmu kalam. Kurikulum keagamaan Islam pada satuan pendidikan diniyyah formal ulya paling sedikit harus memuat mata pelajaran: alQuran, tafsir-ilmu tafsir, hadist-ilmu hadist, tauhid, fiqih-ushul fiqh, akhklaktasawuf, tarikh, bahasa arab, nahwusharf, balaghah, ilmu kalam, ilmu arudh, ilmu mantik, dan ilmu falak. ${ }^{40}$

Sedangkan

kurikulum

pendidikan umum pada satuan pendidikan diniyyah formal ula dan wustha setidaknya paling sedikit memuat mata pelajaran: pendidikan kewarganegaraan, bahasa Indonesia, matematika, dan ilmu pengetahuan alam (IPA). Kemudian, kurikulum pendidikan umum pada satuan pendidikan diniyyah formal ulya setidaknya paling sedikit memuat mata pelajaran: pendidikan kewarganegaraan, bahasa Indonesia, matematika, ilmu pengetahuan alam (IPA), seni dan budaya. ${ }^{41}$

Pendidikan diniyyah nonformal diselenggarakan dalam bentuk: (a) madrasah diniyyah takmiliyah, (b) pendidikan al-Qur'an, (c) majelis taklim, dan (d) pendidikan keagamaan Islam lainnya (pasal 45). Maka, madrasah diniyyah takmiliyah adalah lembaga pendidikan keagamaan Islam pada jalur pendidikan nonformal yang diselenggarakan secara terstruktur dan berjenjang sebagai pelengkap pelaksanaan pendidikan Agama Islam

40 Peraturan Menteri Agama Republilk Indonesia No 13 Tahun 2014 Tentang Pendidikan keagamaan Islam pasal 27.

41 Peraturan Menteri Agama Republilk Indonesia No 13 Tahun 2014 Tentang Pendidikan keagamaan Islam pasal 27. pada jenjang pendidikan dasar, menengah, dan tinggi (pasal 1).

Oleh karena itu, maka madarasah diniyyah takmiliyah diselenggarakan dengan tujuan untuk melengkapi, memperkaya, dan memperdalam pendidikan agama Islam bagi peserta didik MI/SD, MTs/SMP, MS/SMA/SMK/MAK, dan pendidikan tinggi atau yang sederajat dalam rangka peningkatan keimanan dan ketakwaan peserta didik kepada Allah SWT. Madrasah diniyyah memiliki jenjang ula, wustha, ulya, dan al-Jami'ah. Jenjang ula diikuti oleh peserta didik MI/SD atau yang sederajat. Jenjang wustha diikuti oleh peserta didik MTs/SMP atau yang sederajat. Jenjang ulya diikuti oleh peserta didik MA/SMA/MAK/SMK atau yang sederajat. Dan jenjang alJami'ah diikuti oleh peserta didik pada pendidikan tinggi (pasal 46).

Madrasah diniyyah ini diselenggrakan oleh masyarakat secara mandiri maupun terpadu dengan satuan pendidikan lainnya (pasal 47). Sedangkankurikulum madrasah diniyyah takmiliyah ini terdiri atas mata pelajaran pendidikan keagamaan Islam yang paling sedikit meliputi: (a) al-Qur'an, (b) alHadits, (c) Fiqih, (d) Akhlaq, (d) Sejarah Kebudayaan Islam, dan (e) Bahasa Arab (pasal 48).

Sedangkan menurut Karel A. Steenbrink dengan merujuk pada Keputusan Menteri Agama tahun 1964, kurikulum madrasah diniyyah adalah sebagai berikut:

1. Diniyyah Ulaa: Membaca al-Qur'an 3 jam perminggu, tauhid 3 jam perminggu, fiqih 2 jam perminggu, dan akhlak 2 jam perminggu.

2. Diniyyah Wustho: di kelas I dilaksanakan pembelajaran: al- 
Qur'an dan al-Hadits 3 jam perminggu, tauhid 3 jam perminggu, fiqih 1 jam perminggu, sejarah Islam 2 jam perminggu, dan akhlak 1 jam perminggu. Di kelas II dilaksanakan pembelajaran; alQur'an dan al-Hadith 3 jam perminggu, tauhid 3 jam perminggu, fiqih 1 jam perminggu, sejarah Islam 3 jam perminggu, dan akhlak 1 jam perminggu. Di kelas III dilaksanakan pembelajaran; alQur'an dan al- Hadith 3 jam perminggu, tauhid 3 jam perminggu, fiqih 1 jam perminggu, sejarah Islam 3 jam perminggu, dan akhlak 1 jam perminggu.

3. Diniyyah Aliyah: di kelas I dilaksanakan pembelajaran: alQur'an dan al-Hadith 3 jam perminggu, tauhid 2 jam perminggu, fiqih 3 jam perminggu, sejarah Islam 1 jam perminggu, dan akhlak 1 jam perminggu. Di kelas II dilaksanakan pembelajaran; alQur'an dan al-Hadith 3 jam perminggu, tauhid 2 jam perminggu, fiqih 3 jam perminggu, sejarah Islam 1 jam perminggu, dan akhlak 1 jam perminggu. Di kelas III dilaksanakan pembelajaran; alQur'an dan al- Hadith 3 jam perminggu, tauhid 2 jam perminggu, fiqih 3 jam perminggu, sejarah Islam 1 jam perminggu, dan akhlak 1 jam perminggu. ${ }^{42}$

Kemudian Kementerian Agama melakukan penyempurnaan dalam kurikulum madrasah diniyyah, sehingga ditemukan struktur kurikulum madrasah diniyyah takmiliyah dibagi dalam 3 kelompok;

42 Karel A. Steenbrink, Pesantren, Madrasah, Sekolah: Pendidikan Islam dalam Kurun Moderen (Jakarta: LP3ES, 1994). 167168. kelompok mata pelajaran keagamaan, kelompok mata pelajaran bahasa, dan kelompok mata pelajaran muatan lokal. Struktur tersebut dapat dirinci sebagai berikut ${ }^{43}$ :

1. MDTA: kelompok mata pelajaran keagamaan terdiri dari mata pelajaran al-Qur'an 5 jam perminggu di kelas I dan II, 4 jam perminggu di kelas III dan IV; mata pelajaran al-Hadith 1 jam perminggu di kelas I dan II, 2 jam perminggu di kelas III dan IV; mata pelajaran aqidah 2 jam perminggu di kelas I-IV; mata pelajaran fiqih 4 jam perminggu di kelas I-IV, dan mata pelajaran tarikh Islam 1 jam perminggu di kelas I-IV. Kelompok mata pelajaran bahasa terdiri dari mata pelajaran bahasa Arab 4 jam perminggu di kelas I-IV. Kelompok mata pelajaran muatan lokal terdiri dari mata pelajaran Arab pegon, imla' dan lain-lain yang sepenuhnya diserahkan kepada madrasah yang bersangkutan, termasuk juga jam perminggunya.

2. MDTW: kelompok mata pelajaran keagamaan terdiri dari mata pelajaran al-Qur'an 3 jam perminggu di kelas I-II; mata pelajaran al-Hadits 2 jam perminggu di kelas I-II; mata pelajaran aqidah 1 jam perminggu di kelas I-II; mata pelajaran Fiqih 4 jam perminggu di kelas I-II, dan mata pelajaran tarikh Islam pelajaran tarikh Islam 2 jam perminggu di kelas I-II. Kelompok mata pelajaran bahasa terdiri dari mata pelajaran bahasa Arab 4 jam perminggu di kelas I-II. Kelompok mata pelajaran muatan lokal terdiri dari mata pelajaran

43 Kementerian Agama RI, Pedoman Penyelenggaraan Madrasah Diniyah (Surabaya: Kanwil Kementerian Agama Provinsi Jawa Timur, 2015), 23. 
Arab pegon, imla' dan lain-lain yang sepenuhnya diserahkan kepada madrasah yang bersangkutan, termasuk juga jam perminggunya.

3. MDTA: kelompok mata pelajaran keagamaan terdiri dari mata pelajaran al-Qur'an 2 jam perminggu di kelas I-II; mata pelajaran al-Hadith 2 jam perminggu di kelas I-II; mata pelajaran aqidah 2 jam perminggu di kelas I-II; mata pelajaran fiqih 4 jam perminggu di kelas I-II; dan mata pelajaran tarikh Islam 2 jam perminggu di kelas I-II. Kelompok mata pelajaran bahasa terdiri dari mata pelajaran bahasa Arab 4 jam perminggu di kelas I-II. Kelompok mata pelajaran muatan lokal terdiri dari mata pelajaran Arab pegon, imla' dan lain-lain yang sepenuhnya diserahkan kepada madrasah yang bersangkutan, termasuk juga jam perminggunya.

Ketentuan alokasi waktu untuk setiap jam pelajaran dari mata pelajaran tersebut adalah; MDTA (Madrasah Diniyyah Takmiliyah Awwaliyah) Kelas I adalah 30 menit; MDTA Kelas II s.d. IV adalah 40 menit; MDTW (Madarasah Diniyyah Takmiliyah Wustho) Kelas I s.d. II adalah 45 menit; MDTU (Madrasah Diniyyah Takmiliyah Ulya) Kelas I s.d. II adalah 45 menit. ${ }^{44}$

Jadi jenjang pendidikan Madrasah Diniyyah agak disamakan dengan jenjang pendidikan sekolah umum. Untuk pembagiannya, ke dalam 3 tingkatan antara Madrasah Diniyyah awaliyah, wustha, dan ulya itu bervariasi tergantung dengan

44 Kementerian Agama RI, Pedoman Penyelenggaraan Madrasah Diniyah (Surabaya: Kanwil Kementerian Agama Provinsi Jawa Timur, 2015), 23. kemampuan masing-masing siswanya dalam mengaji dan juga biasanya untuk masuk Madrasah Diniyyah tidak harus sesuai dengan tingkatan kelas yang ada di sekolah formal bisa jadi di sekolah formal kelas 3 SD namun ketika di tes untuk mengaji kemampuannya masih kurang sehingga harus masuk kelas dasar lagi ketika di Madrasah Diniyyah.

Mengingat fungsinya sebagai pelengkap bagi pendidikan formal, maka siswa diniyyah takmiliyah adalah anak-anak atau remaja yang di pagi harinya telah mengikuti pendidikan formal baik yang berada di sekolah umum maupun madrasah. Siswa diniyyah takmiliyah tidak ditentukan secara kaku dalam hal usia. Hanya kisarannya mereka memiliki usia selevel usia sekolah, yakni 5 hingga 15 tahun. ${ }^{45}$

Pendidikan al-Quran diselenggarakan oleh masyarakat di masjid, mushalla, ruang kelas, atau ruang belajar lainnya yang memenuhi syarat. Kurikulum pendidikan AlQur'an adalah membaca, menulis dan menghafal ayat-ayat Al-Qur'an, tajwid, serta menghafal doa-doa utama. ${ }^{46}$

Majelis taklim dapat diselenggarakan oleh masyarakat. Di masjid, mushalla, ruang kelas, atau ruang belajar lainnya yang memenuhi syarat. Dalam rangka pemahaman dan pengamalan ajaran Islam.

Pendidikan diniyyah informal diselenggarakan oleh masyarakat dalam rangka meningkatkan pemahaman dan pengalaman ajaran agama Islam dalam bentuk kegiatan

\footnotetext{
45 Mujamil Qomar, Menggagas Pendidikan Islam, (Bandung: Remaja Rosdakarya), 109.

46 Peraturan Menteri Agama Republilk Indonesia No 13 Tahun 2014 Tentang Pendidikan keagamaan Islam pasal 50.
} 
keagamaan Islam di lingkungan keluarga.

\section{Strategi dan Pola Pengembangan Di Diniyyah yang Berwawasan Multikultural}

Strategi dan pola pengembangan di diniyyah yang berwawasan multikultural ini melalui kurikulum yaitu mata pelajaran dan kegiatan ekstrakurikuler serta intrakurikuler. Seperti pada pendidikan diniyyah formal jenjang menengah. Pada kurikulum pendidikan diniyyah formal itu ada mata pelajaran pendidikan kewarganegaraan. Dalam mata pelajaran pendidikan kewarganegaraan, yang ruang lingkupnya meliputi: Persatuan dan Kesatuan Bangsa, Norma Hukum dan Peraturan, Hak Asasi Manusia, kebutuhan Warga negara, Konstitusi Negara, Kekuasaan dan Politik, dan Pancasila. ${ }^{47}$ Pada ruang lingkup pancasila ini, salah satunya ada nilai toleransi beragama yang merupakan salah satu dari nilai-nilai pendidikan multikultural.

Dalam kegiatan ekstrakurikuler pendidikan diniyyah formal ada ekstrakurikuler pramuka. Salah satu contohnya di MAN 3 Sleman Yogyakarta. ${ }^{48}$ Pendidikan multikultural

47 Fatimah, Mariatul Kiptiah, Nur Fajrin, “Integrasi Nilai-Nilai Pendidikan Multikultural dalam Proses Pembelajaran Pendidikan Kewarganegaraan di SMPN 6 Banjarmasin", Jurnal Pendidikan Kewarganegaraan: Volume 4, Nomor 7, Mei 2014, h. 567.

48 Khumaidah dan Ridwan Alawi Sadad, "Analisis Pendidikan Multikultural di Madrasah dan Pesantren: Studi Komparasi di MAN 3 Sleman dan Pondok Pesantren Nurul Ummah Kotagede Yogyakarta", Penangkaran: Jurnal Penelitian Agama dan Masyarakat, Vol 2 No. 1, tahun 2018. H. 109-110. http://ejournal.uin-

suka.ac.id/pusat/panangkaran/article/view/1 $\underline{872}$ diakses tanggal 18 Desember 2020 , pukul 16. 22 WIB. yang dilakukan dalam kegiatan pramuka seperti upacara pembukaan, peraturan baris berbaris (PBB), perkemahan, semapore, morse, sandi, penjelajahan, dan hiburan. Kegiatan tersebut dapat membentuk karakter peserta didik seperti kesetaraan, keadilan, sikap saling menghargai, sikap saling toleransi, dan kemajemukan.

\section{Perbandingan Sistem, Strategi Dan Pola Pendidikan Di Pesantren Dan Diniyyah Yang Berwawasan Multikultural}

Perbandingan sistem, strategi dan pola pendidikan di pesantren dan diniyyah yang berwawasan multikultural, sebagai berikut.

1. Dari segi jalur pendidikan, pondok pesantren dapat dimasukkan ke dalam jalur formal dan non formal, karena pondok pesantren ada yang diselenggarakan secara berjenjang, berkelanjutan dan ada yang tidak. Pondok pesantren yang dilaksanakan secara berjenjang dan berkelanjutan termasuk kedalam jalur pendidikan formal, sedangkan yang tidak berjenjang dan tidak berkelanjutan termasuk jalur pendidikan non formal. Sedangkan diniyyah dapat dimasukkan kedalam jalur formal, nonformal dan informal. karena pendidikan diniyyah ada yang diselenggarakan secara berjenjang, berkelanjutan dan ada yang tidak. pendidikan diniyyah yang dilaksanakan secara berjenjang dan berkelanjutan termasuk ke dalam jalur pendidikan formal, sedangkan yang tidak berjenjang dan tidak berkelanjutan termasuk jalur pendidikan non formal dan informal.

2. Dari segi pendidikan, pondok pesantren dan Diniyyah termasuk 
jenis pendidikan keagamaan Islam, yaitu pendidikan berfungsi mempersiapkan peserta didik menjadi anggota masyarakat yang memahami dan mengamalkan nilai-nilai ajaran agamannya dan atau menjadi ahli ilmu agama.

3. Dari segi jenjang pendidikan, dengan nama dan bentuk yang berbeda-beda, pondok pesantren yang berjenjang dapat dikelompokkan dalam jenjang pendidikan dasar, menengah, dan tinggi, sedangkan diniyyah formal mencakup jenjang pendidikan dasar, menengah, dan tinggi. Pendidikan diniyyah non formal mencakup madrasah diniyyah takmiliyah, pendidikan alQuran dan majelis taklim, dan pendidikan diniyyah informal diselenggarakan di masyarakat dalam bentuk lingkungan keluarga.

4. Dari strategi dan pola pengembangan pendidikan berwawasan multikultural. Di Pesantren, melalui budaya (kegiatan musyawarah dalam membahas masalah hukum) dan literatur-literatur yang menjadi rujukan kitab kuning para santri (kitab ihya 'ulumuddin dan kitab Tanbihul Mughtarin). Pada pendidikan diniyyah melalui mata pelajaran pendidikan kewarganegaraan dan kegiatan ekstrakurikuler yaitu pramuka.

\section{KESIMPULAN}

Perbandingan sistem, strategi dan pola pengembangan pendidikan di pesantren dan diniyyah yang berwawasan multikultural adalah dari segi jalur pendidikan, maka Pondok pesantren dapat dimasukkan kedalam jalur formal dan non formal, sedangkan diniyyah dapat dimasukkan kedalam jalur formal, nonformal dan informal. Selanjutnya dari segi jenjang pendidikan, maka pondok pesantren yang berjenjang dapat dikelompokkan dalam jenjang pendidikan dasar, menengah, dan tinggi, sedangkan Pendidikan diniyyah non formal mencakup madrasah diniyyah takmiliyah, pendidikan alQuran dan majelis taklim, dan pendidikan diniyyah informal diselenggarakan di masyarakat dalam bentuk lingkungan keluarga. Kemudian dari segi strategi dan pola pengembangan pendidikan berwawasan multicultural, maka Di Pesantren, melalui budaya (kegiatan musyawarah dalam membahas masalah hukum) dan literatur-literatur yang menjadi rujukan kitab kuning para santri (kitab ihya 'ulumuddin dan kitab Tanbihul Mughtarin). Pada pendidikan diniyyah melalui mata pelajaran pendidikan kewarganegaraan dan kegiatan ekstrakurikuler yaitu pramuka.

\section{REFERENSI}

Baharun \& Awwaliyah, "Pendidikan Multikultural dalam Menanggulangi Narasi Islamisme di Indonesia". Jurnal Pendidikan Agama Islam (Journal of Islamic Education Studies), 2017.

Baidhawy, Zakiyuddin. (2005). Pendidikan Agama Berwawasan Multikultural. Jakarta: Erlangga

Fatimah, Mariatul Kiptiah, Nur Fajrin, "Integrasi Nilai-Nilai Pendidikan Multikultural dalam Proses Pembelajaran Pendidikan Kewarganegaraan di SMPN 6 Banjarmasin", Jurnal Pendidikan Kewarganegaraan: Volume 4, Nomor 7, Mei 2014. 
Fauzi, A. "Pengembangan Human Relation Perspektif Nilai-nilai alQuran". Mutawatir UIN Sunan Ampel Surabaya, 2015.

Fauzi, Anis. "Pelaksanaan Pendidikan Madrasah Diniyyah di Kota Serang", Jurnal Pendidikan dan Kebudayaan, Vol 1, Nomor 2 , 2016.

Hasbullah. (1995). Sejarah Pendidikan Islam di Indonesia. Raja Grafindo Persada: Jakarta.

https://pontren.com/2016/01/13/me tode-bandongan-pada-pondokpesantren/ diakses pada tanggal 18 Desember 2020, pukul 15. 41 WIb.

Idrus, Muhammad. (2019). Implementasi Pendidikan Tasawuf di Pondok Pesantren dalam Upaya Mencegah Praktek Radikalisme Agama. UIN Maulana Malik Ibrahim Malang.

Kementerian Agama RI. (2015). Pedoman Penyelenggaraan Madrasah Diniyyah Surabaya: Kanwil Kementerian Agama Provinsi Jawa Timur.

Khumaidah dan Ridwan Alawi Sadad, "Analisis Pendidikan Multikultural di Madrasah dan Pesantren: Studi Komparasi di MAN 3 Sleman dan Pondok Pesantren Nurul Ummah Kotagede Yogyakarta”, Penangkaran: Jurnal Penelitian Agama dan Masyarakat, Vol 2 No. 1, tahun 2018. H. 109-110. http://ejournal.uinsuka.ac.id/pusat/panangkaran/ article/view/1872 diakses tanggal 18 Desember 2020 , pukul 16. 22 WIB.
Margono. (2000). Metode penelitian pendidikan. Jakarta: Rineka Cipta.

Mastuhu. (1994). Dinamika Sistem Pendidikan Pesantren: Suatu Kajian Tentang Unsur dan Nilai Sistem Pendidikan Pesantren. Jakarta: INIS.

Muchasan, Ali. "Pendidikan Islam Multikultural di Pesantren (studi kasus di pondok pesantren Sirrojul Ulum Semanding Pare Kediri)", Jurnal Inovatif, Vol 4 No 1, Februari 2018.

Muhtarom. (2005). Reproduksi Ulama di era global: Resistensi Tradisional Islam. Yogyakarta: Pustaka Pelajar.

Peraturan Menteri Agama Republilk Indonesia No 13 Tahun 2014 Tentang Pendidikan keagamaan Islam.

Peraturan Pemerintah Republik Indonesia No 55 Tahun 2007 Tentang Pendidikan Agama dan Keagamaan, pasal 1 ayat 3 .

PORDAM, Jurus Kemensos Cegah Konflik Sosial, https://www.antaranews.com/ berita/1870704/pordam-juruskemensos-cegah-konflik-sosial diakses 14 Desember 2020, pukul 15. 23 WIB.

Qomar, Mujamil. Menggagas Pendidikan Islam. Bandung: Remaja Rosdakarya.

Qomar, Mujamil. (2004). Pesantren: Dari Transformasi Metodologi Menuju Demokratisasi Institusi. Jakarta: Erlangga. 
Rohimin, "Menggagas PAI Multikultural Berbasis alQuran, Jejak dan Pengembangan Nilainilai Multikulturalisme dalam Pendidikan Agama Islam", NUANSA, Vol XI No. 2, Desember 2018.

Steenbrink, Karel A. (1994). Pesantren, Madrasah, Sekolah: Pendidikan Islam dalam Kurun Moderen. Jakarta: LP3ES.

Suharsimi Ari Kunto. (2000). Management Penelitian. Jakarta: Rineka Cipta.

Tim. Strategi pembelajaran di pondok pesantren. Jakarta: Ditpekapontren Kemenag Republik Indonesia (2003).

Undang-Undang Republik Indonesia Nomor 20 tahun 2003 tentang Sistem pendidikan nasional.

Ziemek, Manfred. (1986). Pesantren dan Perubahan Sosial. Jakarta: P3M. 
Perbandingan Strategi dan Pola Pengembangan 